\title{
Assessing wheat spatial variation based on proximal and remote spectral vegetation indices and soil properties
}

\author{
Lorenzo Barbanti, ${ }^{1}$ Josep Adroher, ${ }^{1,2}$ Júnior Melo Damian, ${ }^{1,3}$ Nicola Di Virgilio, ${ }^{4}$ \\ Gloria Falsone, ${ }^{1}$ Matteo Zucchelli, ${ }^{5}$ Roberta Martelli ${ }^{1}$
}

${ }^{1}$ Department of Agricultural and Food Sciences, University of Bologna, Italy; ${ }^{2}$ Department of Chemical and Agricultural Engineering and Agrifood Technology, University of Girona, Spain; ${ }^{3}$ Department of Soil Science, ESALQ, University of São Paulo, Brazil; ${ }^{4}$ Institute of Biometeorology, National Research Council, Bologna, Italy; ${ }^{5}$ Trimble Italia, Vimercate (MB), Italy

\begin{abstract}
Assessing the spatial variation of soil and crop properties is the basis for site specific management of crop practices in precision agriculture applications. To this aim, proximal and remote spectral vegetation indices are increasingly replacing soil analysis. In this study the spatial variation of soil properties, proximal and remote spectral vegetation indices were compared in a winter wheat (Triticum aestivum L.) crop grown in a 4.15 ha field in northern Italy. Soil analysis (particle size distribution, $\mathrm{pH}$, carbonates, $\mathrm{C}$, total $\mathrm{N}$, available $\mathrm{P}$, exchangeable cations and electrical conductivity) was geo-referentially carried out; the proximal indices chlorophyll content by N-Tester and normalised difference vegetation index through GreenSeeker were determined in three dates during stem elongation; the remote indices PurePixel ${ }^{\mathrm{TM}}$ chlorophyll index and PurePixel ${ }^{\mathrm{TM}}$ vegetation index were determined through the Landsat 8 satellite in three dates during the same wheat stage. Dry biomass yield (DBY), grain yield (GY) and yield components were
\end{abstract}

Correspondence: Nicola Di Virgilio, Institute of Biometeorology, National Research Council, via Gobetti 101, 40129 Bologna, Italy.

Tel.: +39.051.6399014 - Fax: +39.051.6399024.

E-mail: n.divirgilio@ibimet.cnr.it

Key words: Precision agriculture; soil properties; remote vegetation indices; wheat; yield mapping.

Acknowledgements: Claudio Mazzotti and Alessandra Miserocchi of the Agrisfera Cooperative are gratefully acknowledged for the support during the field experiment. CAPES Foundation, Ministry of Education of Brazil, is acknowledged for scholarship no. 88888.019221/2013-00 enabling JMD to participate to the research described in this paper.

Conference presentation: SIA XLVI Congress, Milan, 2017.

Received for publication: 7 August 2017.

Revision received: 17 October 2017.

Accepted for publication: 18 October 2017.

(C) Copyright L. Barbanti et al., 2018

Licensee PAGEPress, Italy

Italian Journal of Agronomy 2018; 13:1086

doi:10.4081/ija.2017.1086

This article is distributed under the terms of the Creative Commons Attribution Noncommercial License (by-nc 4.0) which permits any noncommercial use, distribution, and reproduction in any medium, provided the original author(s) and source are credited. determined at harvest. Soil, proximal and remote data were submitted to principal component analysis (PCA), and the retained PCs were clustered to delineate areas at low, intermediate and high yield potential, based on soil parameters $\left(\mathrm{CLU}_{\mathrm{sp}}\right)$, proximal $\left(\mathrm{CLU}_{\mathrm{pi}}\right)$, and remote vegetation indices $\left(\mathrm{CLU}_{\mathrm{ri}}\right)$. DBY and $\mathrm{GY}$ were significantly correlated with several soil parameters and vegetation indices. Spatial distribution of soil and crop data consistently depicted a low performing area $\left(\mathrm{GY}<3 \mathrm{Mg} \mathrm{ha}^{-1}\right)$ and a high performing one $\left(\mathrm{GY}>8 \mathrm{Mg} \mathrm{ha}^{-1}\right)$. $\mathrm{CLU}_{\mathrm{sp}}$ determined a lower GY difference between low and high performing area ( $+60 \%)$, compared to $\mathrm{CLU}_{\mathrm{pi}}$ and $\mathrm{CLU}_{\mathrm{ri}}($ almost $+100 \%)$. In $\mathrm{CLU}_{\mathrm{sp}}$ and $\mathrm{CLU}_{\mathrm{pi}}$ the low and high performing area were of similar size (25 and 29\% for the two respective areas in $\mathrm{CLU}_{\mathrm{sp}} ; 25$ and $33 \%$ in $\mathrm{CLU}_{\mathrm{pi}}$ ), whereas in $\mathrm{CLU}_{\mathrm{ri}}$ they were quite different (16 and 46\%). Lastly, yield potential levels determined by vegetation indices (CLU $\mathrm{Ci}_{\mathrm{pi}}$ and $\left.\mathrm{CLU}_{\mathrm{ri}}\right)$ exhibited a better degree of agreement with DBY and GY levels, than soil parameters $\left(\mathrm{CLU}_{\mathrm{sp}}\right)$. In exchange for this, the above referred soil parameters are quite consistent in time, allowing soil data to be used for more years. On concluding, PCA followed by clustering resulted in a robust delineation of field areas at different yield potential. This is the premise for developing research driven strategies of practical use.

\section{Introduction}

The sustainable improvement of wheat production is strongly associated with the supply of crop inputs in a frame of precision agriculture (PA) practices (Diacono et al., 2013; Yousefi and Razdari, 2015). This means supplementing the wheat crop with the amount of each input that maximises yield in light of spatially- and temporally-variable growth conditions. Thus, different areas of a field are managed in a specific way to achieve full yield potential.

This principle is faced by many difficulties in PA implementation. Therefore, despite early enthusiasm following the first applications in the 1980's (Stafford, 2000), PA has not achieved widespread adoption (Yousefi and Razdari, 2015). In fact, although considerable effort has been spent by research and extension services in many countries, only a portion of farmers is willing to apply any type of PA technologies (Reichardt and Jürgens, 2009).

Implementation of PA was initially based on the utilisation of existing machinery, by adding controllers and global navigation satellite system to enable vehicle guidance and self-steering. This was due to the financial benefits that were readily achieved without the need for much, or any, decision support system or compo- 
nent integration (McBratney et al., 2005). To date, the leading application of PA is the site-specific supply of fertilisers by means of variable rate spreaders (Chen et al., 2014).

PA adoption is affected by an insufficient appraisal of crop temporal variation, and the need of a suitable decision support system (McBratney et al., 2005). Moreover, the integration of data obtained from soil and crop sensing into decision support systems has not achieved univocal consensus (Zhang and Kovacs, 2012). This urges for the development of simple strategies to support the decision making process. In turn, this will allow farmers to overcome the background noise originating from data collection, analysis and management, while concurrently dealing with the technical advances in crop sensing, yield monitoring and computer processing (Mulla and Schepers, 1997; Lowrance et al., 2016).

The spatial variability of soil and crop properties is still largely unknown even in cereals that, owing to their large surface, are best suited for site-specific management (SSM). SSM allows a field to be split into areas that express a relatively homogeneous combination of yield limiting factors, for which a single rate of a specific crop input is appropriate (Fridgen et al., 2004; Chang et al., 2014; Damian et al., 2016). The choice of the algorithm for delineating such areas is another point of debate, although data clustering is a widely accepted method, and fuzzy c-means algorithms are one of the most common techniques for data clustering (Guastaferro et al., 2010).

The cost and time needed to obtain the information to set up homogeneous sub-field areas represent a constraint that is largely responsible for the slow progress in SSM (Pierce and Novak, 1999; Lowrance et al., 2016). Thus, alternative methods are sought to replace crop records (Blackmore, 2000; Milne et al., 2012), soil properties (Kitchen et al., 2005; Chang et al., 2014), and their combination (Li et al., 2008; Mann et al., 2011), which are still widely used at present.

The optical sensing of crop properties includes many methods potentially serving this task. One of the most diffused is the assessment of the normalised difference vegetation index (NDVI), which is the ratio between the difference and the sum of canopy reflectance in the near infra-red (NIR) $(780 \mathrm{~nm})$ and red $(670 \mathrm{~nm})$, providing an indication of crop health and vigour (Tucker, 1979). The NDVI has been widely used in the wheat crop to support biomass and grain yield predictions (Erdle et al., 2011; Grohs et al., 2011; Quebrajo et al., 2015; Bushong et al., 2016), assess optimum N fertiliser doses (Macnack et al., 2014; Calvo et al., 2015; Samborski et al., 2015), and for other uses as mapping crop areas (Patil et al., 2010; Jin et al., 2016), and estimating water requirements (Chattaraj et al., 2013; Ozcan et al., 2014).

The NDVI is still at present the reference spectral vegetation index, although limits have been evidenced compared to other indices operating in the same wavebands (Erdle et al., 2011; Samborski et al., 2015). Sometimes, better estimates of grain yield and quality were obtained when NDVI was integrated by environmental parameters as soil moisture, precipitation and cumulated heat during wheat growth (Macnack et al., 2014; Bushong et al., 2016). One of the drawbacks associated with NDVI assessed through active optical sensors is the need to operate at, or near, ground level. This involves the development of specific skills in the management of optical sensors, mounted on a ground or aerial (unmanned) vehicle. Owing to this, remote sensing from satellites is gaining interest over proximal sensing from ground or low altitude platforms. However, also remote sensing has weak points: the influence of weather conditions during data acquisition, the spatial and temporal scale, and the problems associated with processing and evaluation of spectral images (Zhang and Kovacs, 2012). In exchange for this, the use of satellites operating in various wavebands of the visible and NIR originates a number of vegetation indices being developed as potential substitutes for NDVI (Patil et al., 2010; Basso et al., 2016).

Given the pending problems in the adoption of PA practices, owing to the uncertainties in the assessment of wheat spectral indices, this work addressed the study of proximal $v s$. remote vegetation indices, and soil properties, in the interpretation of wheat spatial variation. The study was intended as a showcase for the methodology to study spatial variability and define homogeneous areas in a year of survey using soil parameters vs. near and remote indices.

\section{Materials and methods}

\section{Study area}

The study was conducted in 2014 in the coastal plain near Ravenna, Italy ( $44^{\circ} 29^{\prime} \mathrm{N}, 12^{\circ} 07^{\prime} \mathrm{E}, 0 \mathrm{~m}$ a.s.1.). A 4.15 ha experimental area $(72 \times 576 \mathrm{~m})$ cultivated with winter wheat (Triticum aestivum L.) was chosen within a larger field (ca. 20 ha) of the Agrisfera Cooperative, using a GPS device (Garmin International Inc., Olathe, KS, USA) to set borders. Wheat (cv. Aquilante) was seeded in November 2013 on soil ploughed at $0.3 \mathrm{~m}$ depth. Preceding crop was coriander. Wheat management was based on the good practice for the specific crop: fertilisation consisted of two top dress applications of 54 and $92 \mathrm{~kg} \mathrm{ha}^{-1}$ of $\mathrm{N}$, respectively; one herbicide spraying was carried out at tillering; one insecticidefungicide mixture was sprayed at heading.

\section{Soil and crop data}

\section{Soil analysis}

Soil samples (0-0.3 m depth) were taken on March 12, 2014 in a 24-cell grid $\left(48 \times 36 \mathrm{~m}\right.$; cell size $\left.1728 \mathrm{~m}^{2}\right)$, which was established with the CR-Campeiro 7 software (Giotto and Robaina, 2007). Each sample was composed of four cores equally spaced from the plot centre. The samples were oven dried at $40^{\circ} \mathrm{C}$ and ground to pass a $2 \mathrm{~mm}$ sieve. The following parameters were assessed: particle size distribution (sand, silt and clay), $\mathrm{pH}$, total carbonates $\left(\mathrm{CaCO}_{3}\right)$, total organic carbon $(\mathrm{C})$, total nitrogen $(\mathrm{N})$, available $\mathrm{P}$ (Olsen), exchangeable cations $(\mathrm{K}, \mathrm{Ca}, \mathrm{Mg}, \mathrm{Na})$, cation exchange capacity (CEC), exchangeable sodium percentage (ESP), and electrical conductivity (ECe). The analytical methods of the Italian protocol for soil analysis (D.M. 13/09, 1999) were adopted, apart from CEC that was determined by means of cobalt hexamine trichloride (Orsini and Rémy, 1976, modified by Ciesielski and Sterckeman, 1977), and C and N that were determined by dry combustion (CHNS-O mod. EA 1110, Thermo Scientific GmbH, Dreieich, Germany), using acetanilide as a standard for $\mathrm{C}$ and $\mathrm{N}$ concentration.

\section{Proximal sensing of spectral vegetation indices}

Proximal indices were assessed in a 36 -cell grid $(36 \times 36 \mathrm{~m}$; cell size $1152 \mathrm{~m}^{2}$ ), using two hand held devices: i) the chlorophyll meter N-Tester (NT) (Yara International ASA, Oslo, Norway), which measures leaf transmittance in the red $(650 \mathrm{~nm})$ and infrared (940 nm) wavelengths, indicating a numeric value that is proportional to leaf chlorophyll content (Diacono et al., 2013); ii) the active radiometer GreenSeeker (GS) (NTech Industries, Inc., Ukiah, CA, USA), which measures canopy reflectance in the red $\left(R_{R E D}\right)(650 \pm 10 \mathrm{~nm})$ and NIR $\left(R_{N I R}\right)(770 \pm 15 \mathrm{~nm})$ band, and calcu- 
lates NDVI as index of general crop status (Raun et al., 2001) according to the formula: NDVI $=\left(R_{N I R}-R_{R E D}\right) /\left(R_{N I R}+R_{R E D}\right)$.

Chlorophyll assessment with NT was carried out on the youngest fully developed leaf at 14-day intervals from mid March to mid June. NDVI appraisal with GS was performed concurrently. For both indices, three dates from March 21 to April 24, 2014 were retained for the present work, covering a range of wheat stages from early stem elongation to heading (Table 1).

\section{Remote sensing of spectral vegetation indices}

Remote indices were based on the operational land imager (OLI) multispectral sensor $(15 \times 15 \mathrm{~m}$ spatial resolution) of the Landsat 8 satellite that has a revisiting frequency of 9-15 days. The raw images were processed by Trimble Agriculture Division to remove the interfering factors and produce pure spectral signatures. Multiple spectral bands going from the visible to the nearinfrared spectral region were used, and the OLI scene was atmospherically corrected through the application of a custom Trimble Agriculture Division algorithm. Two indices were obtained by means of calibration to ensure time comparisons, in the frame of PurePixel $^{\mathrm{TM}}$ vegetation maps: the PurePixel chlorophyll index (PPCI) indicating chlorophyll content, and the PurePixel vegetation index (PPVI) that is related to general growth status. PPCI and PPVI are the remote indices corresponding to the proximal indices NT and GS, respectively. The images acquired in three dates from March 15 to April 16, 2014, were retained for the present work (Table 1).

\section{Plant morphology and grain characteristics at maturity}

Wheat development was assessed through the Zadoks scale (Zadoks et al., 1974) at 14-day intervals from early stem elongation to full maturity (March-June). At heading, plant height and spike density, i.e. the number of spikes per square meter $\left(\mathrm{S} / \mathrm{m}^{2}\right)$, were assessed in the 36-cell grid. At maturity, plant samples were collected on $0.9 \mathrm{~m}^{2}$ in the central position of each cell. At the laboratory, spikes were threshed, and the two components of plant biomass (grain and straw) were weighed and oven $\operatorname{dried}\left(105^{\circ} \mathrm{C}\right)$ for moisture determination. Grain and straw dry weight, coupled with $\mathrm{S} / \mathrm{m}^{2}$, allowed us to calculate the number of grains per spike $(\mathrm{G} / \mathrm{S})$, and determine mean grain weight $(\mathrm{MGW})$, test weight $\left(\mathrm{dg} \mathrm{L} \mathrm{L}^{-1}\right)$, dry biomass yield (DBY) and harvest index as the ratio of grain to total plant biomass on a dry weight basis. Grain samples were also submitted to the analysis of total nitrogen $(\mathrm{N})$ using the same procedure of soil analysis. $\mathrm{N}$ content was multiplied by 5.7 to obtain grain protein content (GPC) $\left(\mathrm{g} \mathrm{kg}^{-1}\right.$ on a dry weight basis).

Soil parameters, proximal and remote vegetation indices, crop traits, and the respective growth stages are summarised in Table 1.

\section{Harvest data}

Combine harvesting was carried out at full wheat maturity on July 7, 2014. A New Holland CR 9080 (CNH Industrial N.V., Basildon, UK) harvester was used, which was equipped with assisted guiding system based on real time kinematic GPS, and yield mapping system consisting of a Pektron flow meter (Pektron Group Ltd, Derby, UK) and Ag Leader moisture sensor (Ag Leader Technology, Ames, IA, USA). Raw yield data acquired at $0.2 \mathrm{~Hz}$ frequency were filtered using Yield Editor software (Sudduth et al., 2007), adjusted at 13\% moisture, and geo-referenced through the Farm Works software (Trimble Navigation Ltd., Sunnyvale, CA, USA) to obtain the final grain yield (GY) data. Operating in this way, a total of $4160 \mathrm{GY}$ data points was archived in the experimental area.

\section{Data analysis and map creation}

Soil parameters, spectral vegetation indices and plant traits were subjected to descriptive statistics: mean, median, minimum, maximum, standard deviation, coefficient of variation (CV), skewness and kurtosis were assessed. Normal distribution of data was controlled through the Kolmogorov-Smirnov (K-S) test.

Pearson's correlation (r) was assessed to evaluate the relationship of soil trait, proximal and remote indices, with GY and related traits. To avoid additional variation due to estimation of values in non-surveyed locations (Tagarakis et al., 2013), actual GY data recorded at harvest were used: the spatial resolution of these values (4160 data points) exceeded those of soil parameters, proximal and remote indices, thus permitting their correlation with the closest GY values. Descriptive statistics and Pearson's correlations were run with the Statistica 10 software (StatSoft, Tulsa, OK, USA).

Map creation was performed using the open source software Quantum GIS 2.2.0 (OSGeo, Beaverton, OR, USA) to geographically locate measured data of soil parameters, proximal and remote vegetation indices, and GY. Continuous maps of these traits including contour iso-lines were created for graphical representation of data. Survey points were interpolated using the inverse distance weighting (IDW) interpolation method. IDW assumes that each point value has a local influence that decreases with distance (Bonham-Carter, 1994).

\section{Clustering}

Sub-division of the experimental field into homogeneous areas was based on clustering with three different criteria: soil parameters, proximal and remote vegetation indices. In each case, a maximum of three clusters was set as the number fostering sufficient differentiation while avoiding excessive fragmentation of crop practices (Lawrence et al., 2016). To overcome the complexity and the multiple inter-relations of the soil data set composed of 14 parameters, a principal component analysis (PCA) was run to reduce the number of variables to a meaningful few (Dunteman, 1989; Mallarino et al., 1999; Fraisse et al., 2001). Thereafter, fuzzy c-means clustering that represents an unsupervised continuous classification procedure, was performed on data of the PCs retained from the analysis (Li et al., 2013). The Management Zone Analyst software (MZA 1.01; University of Missouri-Columbia, USA) (Fridgen et al., 2004) was used, adopting Euclidean distances of data points from cluster centres.

PCA was also run on proximal and remote vegetation indices.

Table 1. Soil parameters, proximal and remote vegetation indices and crop assessments at the respective growth stages.

\begin{tabular}{|c|c|c|c|}
\hline \multirow[t]{2}{*}{ Date } & \multicolumn{2}{|c|}{ Growth stage } & \multirow[t]{2}{*}{ Assessment } \\
\hline & Zadoks scale & Description & \\
\hline March 12 & 30 & Early stem elongation & Soil analysis \\
\hline March 15 & 34 & $1^{\text {st }}$ node & PPCI, PPVI \\
\hline March 25 & 32 & $2^{\text {nd }}$ node & NT, GS \\
\hline March 31 & 34 & $4^{\text {th }}$ node & PPCI, PPVI \\
\hline April 8 & 37 & Flag leaf just visible & NT, GS \\
\hline April 16 & 45 & Booting & PPCI, PPVI \\
\hline April 24 & 58 & Ear almost fully emerged & NT, GS \\
\hline May 7 & 69 & End of flowering & Plant height, $\mathrm{S} / \mathrm{m}^{2}$ \\
\hline June 24 & 91 & Ripening & HI, MGW, G/S, TW, GPC \\
\hline
\end{tabular}

PPCI, PurePixel chlorophyll index; PPVI, PurePixel vegetation index; NT, N-Tester; GS, GreenSeeker; S/m², spike density; HI, harvest index; MGW, mean grain weight; G/S, grains per spike; TW, test weight; GPC, grain protein content. 
Two indices $\mathrm{x}$ three dates (Table 1) were submitted to PCA in proximal indices, and the same was done in remote indices. Fuzzy cmeans clustering was then performed on the PCs retained, as in the case of soil parameters. To assess the ability of the three criteria to delineate areas at different crop behaviour, data of plant morphology, yield and quality associated with the homogeneous areas established with the three criteria were submitted to a one-way ANOVA through the Statistica 10 software (StatSoft, Tulsa, OK, USA). The least significant difference at $\mathrm{P} \leq 0.05$ was used to separate means of significantly different traits.

Additionally, a cell-by-cell comparison was conducted between the DBY and GY level associated with each cell, obtained through independent clustering with the above methods, and the level determined for that cell by clustering with the three criteria. Of the three levels assigned, low (L), intermediate (I) and high (H), the percentage of cells belonging to the same level in the two scales was used to indicate the degree of agreement between clusters based on either criteria, on one side, and DBY and GY, on the other side (Tagarakis et al., 2013). Mild disagreement was shown in those cases where only one class separated the rating given by the two scales, whereas strong disagreement was evidenced when the rating diverged by two classes.

\section{Results}

\section{Descriptive statistics}

\section{Soil parameters}

Soil texture ranged from loamy to sandy-loamy (Table 2), owing to a noticeable variation in the three classes of particle size distribution ( $\mathrm{CV}$ between 26 and 32\%). The $\mathrm{pH}$ was from moderately to strongly alkaline, in association with high $\mathrm{CaCO}_{3}$ content. No risk of sodium or salinity was evidenced, given a low amount of Na determining a very low ESP (average, $0.11 \%$ ), and a negligible level of electrical conductivity $\left(\mathrm{EC}_{\mathrm{e}}\right.$ ) (average, $0.16 \mathrm{dS} \mathrm{m} \mathrm{m}^{-1}$ ) (ESP and $\mathrm{EC}_{\mathrm{e}}$ data not shown). Organic carbon was always low, as no sample attained $10 \mathrm{~g} \mathrm{C} \mathrm{kg}^{-1}$. $\mathrm{C}$ and $\mathrm{N}$ varied concurrently, resulting in a low $\mathrm{C} / \mathrm{N}$ ratio. This indicates a soil prone to $\mathrm{C}$ loss due to prevailing mineralisation processes.

$\mathrm{P}$ and $\mathrm{K}$ were in the low range of the respective scales of evaluation (D.M. 13/09, 1999), and K was the soil parameter affected by the largest variation (CV, 35\%). Lastly, the CEC was relatively low, which is consistent with a modest clay and organic $\mathrm{C}$ content.

Table 2. Descriptive statistics of soil parameters.

\begin{tabular}{|c|c|c|c|c|c|c|c|c|c|}
\hline Trait & Mean & Median & Min. & Max. & SD & CV & Skewness & Kurtosis & $\mathrm{K}-\mathrm{S}$ \\
\hline Sand $\left(\mathrm{g} \mathrm{kg}^{-1}\right)$ & 513 & 510 & 314 & 773 & 134 & 26.1 & 0.22 & -0.89 & ns \\
\hline Silt $\left(\mathrm{g} \mathrm{kg}^{-1}\right)$ & 379 & 376 & 195 & 544 & 104 & 27.3 & -0.15 & -0.90 & ns \\
\hline Clay $\left(\mathrm{g} \mathrm{kg}^{-1}\right)$ & 108 & 114 & 32 & 163 & 35 & 31.8 & -0.22 & -0.69 & ns \\
\hline $\mathrm{pH}$ & 8.4 & 8.4 & 8.3 & 8.7 & 0.1 & 1.2 & 0.81 & 0.71 & ns \\
\hline $\mathrm{CaCO}_{3}\left(\mathrm{~g} \mathrm{~kg}^{-1}\right)$ & 204 & 206 & 170 & 232 & 16 & 7.9 & -0.56 & 0.02 & ns \\
\hline $\mathrm{C}\left(\mathrm{g} \mathrm{kg}^{-1}\right)$ & 6.5 & 6.7 & 3.4 & 9.1 & 1.5 & 22.4 & -0.40 & 0.05 & ns \\
\hline $\mathrm{N}\left(\mathrm{g} \mathrm{kg}^{-1}\right)$ & 1.1 & 1.1 & 0.7 & 1.3 & 0.1 & 11.7 & -1.12 & 2.78 & ns \\
\hline $\mathrm{C} / \mathrm{N}$ & 6.1 & 6.3 & 4.2 & 8.3 & 1.0 & 16.4 & 0.23 & 0.23 & ns \\
\hline Available P (mg kg-1) & 8.1 & 7.7 & 6.4 & 10.9 & 1.2 & 15.1 & 0.85 & -0.02 & ns \\
\hline Exch. K (mg kg-1) & 47.0 & 43.6 & 22.4 & 82.4 & 16.6 & 35.4 & 0.49 & -0.56 & ns \\
\hline Exch. Ca $\left(\mathrm{mg} \mathrm{kg}^{-1}\right)$ & 2310 & 2371 & 1877 & 2568 & 197 & 8.5 & -0.56 & -0.87 & ns \\
\hline Exch. Mg (mg kg-1) & 67.3 & 72.6 & 29.5 & 92.2 & 17.5 & 25.9 & -0.65 & -0.52 & ns \\
\hline Exch. Na (mg kg-1) & 3.0 & 3.0 & 2.9 & 3.3 & 0.1 & 3.7 & 0.92 & 1.64 & ns \\
\hline $\mathrm{CEC}\left(\mathrm{cmol}_{\mathrm{c}}{ }^{+} \mathrm{kg}^{-1}\right)$ & 14.4 & 15.4 & 7.3 & 20.3 & 2.9 & 20.1 & -0.76 & 1.10 & ns \\
\hline
\end{tabular}

SD, standard deviation; CV, coefficient of variation; K-S, significance at the Kolmogorov-Smirnov test for normal distribution; ns, not significant; CEC, cation exchange capacity.

Table 3. Descriptive statistics of proximal and remote spectral vegetation indices.

\begin{tabular}{|c|c|c|c|c|c|c|c|c|c|}
\hline Variable & Mean & Median & Min. & Max. & SD & CV & Skewness & Kurtosis & K-S \\
\hline \multicolumn{10}{|c|}{ Proximal indices } \\
\hline NT $3 / 25$ & 407 & 412 & 319 & 437 & 23 & 5.7 & -1.92 & 5.34 & ns \\
\hline GS $3 / 25$ & 0.66 & 0.68 & 0.47 & 0.78 & 0.09 & 13.8 & -0.55 & -0.84 & ns \\
\hline NT $4 / 8$ & 427 & 421 & 347 & 494 & 43 & 10.2 & 0.06 & -1.00 & ns \\
\hline GS $4 / 8$ & 0.73 & 0.77 & 0.47 & 0.80 & 0.08 & 11.2 & -1.57 & 2.12 & $*$ \\
\hline NT 4/24 & 460 & 465 & 288 & 557 & 66 & 14.3 & -0.84 & 0.20 & ns \\
\hline GS $4 / 24$ & 0.74 & 0.76 & 0.53 & 0.78 & 0.05 & 7.3 & -2.57 & 7.20 & $*$ \\
\hline \multicolumn{10}{|c|}{ Remote indices } \\
\hline PPCI 3/15 & 80.0 & 82.0 & 52.0 & 92.0 & 10.9 & 13.6 & -3.48 & 21.07 & $* *$ \\
\hline PPVI 3/15 & 59.5 & 60.0 & 40.0 & 73.0 & 9.0 & 15.2 & -0.25 & -0.99 & ns \\
\hline PPCI 3/31 & 74.6 & 76.0 & 55.0 & 82.0 & 5.2 & 7.0 & -1.72 & 3.19 & $* *$ \\
\hline PPVI 3/31 & 79.8 & 82.0 & 58.0 & 89.0 & 7.8 & 9.7 & -0.72 & -0.26 & ns \\
\hline PPCI 4/16 & 79.7 & 81.0 & 64.0 & 89.0 & 5.5 & 7.0 & -0.78 & 0.22 & $*$ \\
\hline PPVI 4/16 & 83.3 & 84.0 & 68.0 & 90.0 & 4.9 & 5.9 & -1.03 & 0.62 & $* *$ \\
\hline
\end{tabular}

$\mathrm{SD}$, standard deviation; CV, coefficient of variation; K-S, significance at the Kolmogorov-Smirnov test for normal distribution; ns, ${ }^{*}$ and ${ }^{* *}$, not significant and significant at $\mathrm{P} \leq 0.05$ and $\mathrm{P} \leq 0.01$, respectively; NT, N-Tester; GS, GreenSeeker; PPCI, PurePixel chlorophyll index; PPVI, PurePixel vegetation index. 


\section{Proximal and remote spectral vegetation indices}

NT increased from stem elongation $(3 / 25)$ to ear emergence (4/24), which is consistent with an increase in chlorophyll content between the two stages (Table 3 ). NT variation also increased between the two stages (CV from 5.7 to $14.3 \%$ ).

GS increased in parallel to NT, as consequence of the wheat plant attaining peak growth. GS variation decreased with time, but data became non-normally distributed (significant K-S test at the second and third time). Both NT and GS portrayed a generally modest variation.

PPCI did not substantially increase between early stem elongation (3/15) and booting (4/16) (Table 3). This is in contrast to NT that is the proximal index addressing chlorophyll content. PPCI variation was quite low and decreasing between the two stages.

PPVI noticeably increased during the same period (Table 3), in accordance with GS that is the equivalent proximal index. PPVI variation decreased in time, still in accordance with GS variation.

\section{Plant morphology, yield and quality}

Plant height varied between ca. 0.5 and $1 \mathrm{~m}$ (Table 4). The mean value was closer to the highest value and the variation was quite low (CV,13\%), suggesting that only a small field fraction was affected by poor growth conditions. DBY staged a higher variation than plant height $(\mathrm{CV}, 25 \%)$. Conversely, HI showed a tight range and a typical mean value (0.50). This suggests that in poor field areas wheat growth was constrained since an early stage, resulting in stunted plants producing a few grain.

GY exhibited a normal mean value for winter wheat grown in the region of the experiment $\left(6.25 \mathrm{Mg} \mathrm{ha}^{-1}\right)$. The sizeable variation $(\mathrm{CV}, 27 \%)$ reflects contrasting changes in the three yield components: G/S and MGW staged the highest and lowest variation, respectively. Thus, wheat response to variable growth conditions determined morphological changes influencing spike fertility $(\mathrm{G} / \mathrm{S})$ more than spike density $\left(\mathrm{S} / \mathrm{m}^{2}\right)$, in turn more than MGW.

Lastly, the two traits addressing grain quality, TW and GPC, exhibited a respective high and modest level, in both cases with limited variation.

\section{Relationships between soil and spectral vegetation data, and plant traits}

Plant height and HI were significantly correlated with many soil parameters and vegetation indices (Table 5): negative relationships were shown with sand and $\mathrm{pH}$, whereas positive relationships were evidenced with silt, clay, $\mathrm{C}, \mathrm{N}$, their ratio, and with all proximal and remote vegetation indices.

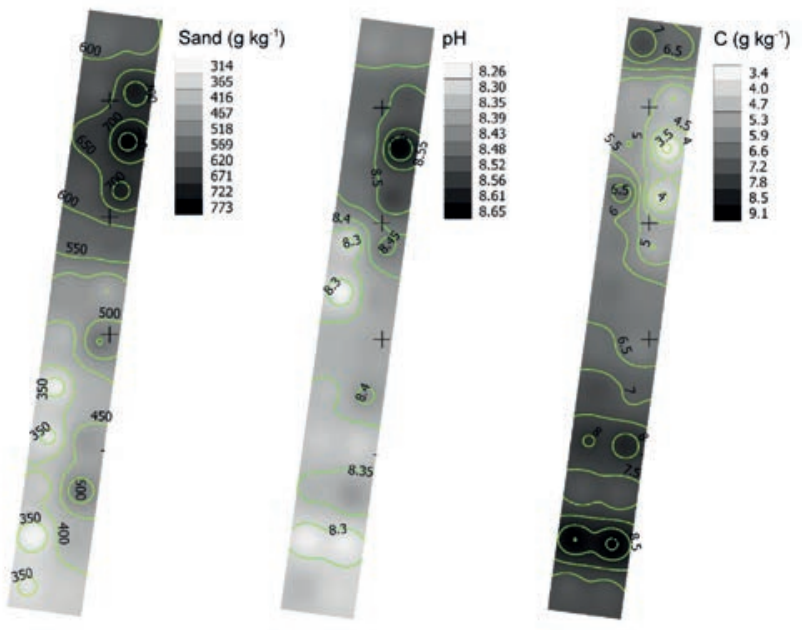

Figure 1. Smoothed contour maps for the soil parameters sand, $\mathrm{pH}$, and total organic $\mathrm{C}$.

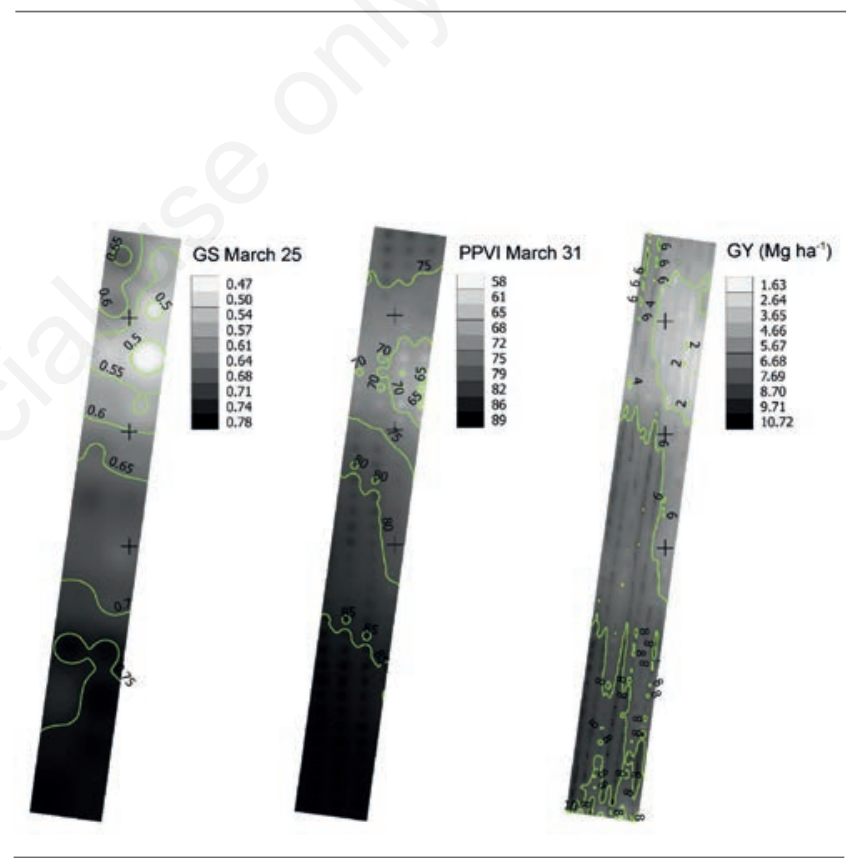

Figure 2. Smoothed contour maps for the spectral vegetation index GreenSeeker (GS) at March 25, PurePixel vegetation index (PPVI) at March 31, and final grain yield (GY).

Table 4. Descriptive statistics of plant morphology, yield and quality traits.

\begin{tabular}{|c|c|c|c|c|c|c|c|c|c|}
\hline Variable & Mean & Median & Min. & Max. & SD & CV & Skewness & Kurtosis & $\mathrm{K}-\mathrm{S}$ \\
\hline Height (m) & 0.83 & 0.86 & 0.51 & 0.99 & 0.11 & 13.2 & -1.14 & 1.35 & ns \\
\hline DBY $\left(\mathrm{Mg} \mathrm{ha}^{-1}\right)$ & 10.90 & 11.55 & 4.40 & 14.59 & 2.68 & 24.6 & -0.55 & -0.47 & ns \\
\hline $\mathrm{HI}(\mathrm{w} / \mathrm{w})$ & 0.50 & 0.50 & 0.40 & 0.55 & 0.03 & 6.2 & -1.03 & 1.68 & ns \\
\hline GY $\left(\mathrm{Mg} \mathrm{ha}^{-1}\right)$ & 6.25 & 6.66 & 2.42 & 8.57 & 1.70 & 27.3 & -0.46 & -0.79 & ns \\
\hline $\mathrm{S} / \mathrm{m}^{2}\left(\right.$ no. $\left.\mathrm{m}^{-2}\right)$ & 574 & 579 & 458 & 688 & 61 & 10.7 & -0.13 & -0.93 & ns \\
\hline G/S (no. spike ${ }^{-1}$ ) & 25.3 & 26.9 & 9.6 & 41.8 & 8.1 & 32.2 & -0.33 & -0.44 & ns \\
\hline MGW (mg) & 39.4 & 39.8 & 33.6 & 42.2 & 1.8 & 4.5 & -1.04 & 2.05 & ns \\
\hline TW (dg $\left.\mathrm{L}^{-1}\right)$ & 83.7 & 83.8 & 79.8 & 85.8 & 1.2 & 1.5 & -1.29 & 2.54 & ns \\
\hline $\mathrm{GPC}\left(\mathrm{g} \mathrm{kg}^{-1}\right)$ & 100.9 & 101.5 & 75.8 & 133.4 & 14.1 & 13.9 & 0.35 & -0.30 & ns \\
\hline
\end{tabular}

$\mathrm{S} / \mathrm{m}^{2}$, spike density; G/S, grains per spike; MGW, mean grain weight; TW, test weight; GPC, grain protein content. 
DBY and GY were also significantly correlated with many soil parameters and vegetation indices (Table 5). These relationships substantially reflect those above referred involving plant height and HI, two traits significantly correlated with yield (data not shown). It is worth noting that the two indices of chlorophyll content (NT and PPCI) exhibited improved correlations with DBY and $\mathrm{GY}$ as time proceeded, in contrast to the two indices of general plant status (GS and PPVI). In general, DBY showed higher correlations with vegetation indices than GY.

Concerning the three yield components, spike density $\left(\mathrm{S} / \mathrm{m}^{2}\right)$ was poorly correlated with all soil and vegetation data, whereas spike fertility $(\mathrm{G} / \mathrm{S})$ and $\mathrm{MGW}$ were correlated with many soil parameters and all vegetation indices (Table 5).

Lastly, the two traits addressing grain quality (TW and GPC) were generally weakly related with soil parameters and proximal indices. The correlations got stronger and were always negative when passing to remote vegetation indices. GPC was generally better correlated than TW.

\section{Spatial distribution of soil and crop data}

Continuous maps of the three soil parameters and the two vegetation indices featuring the highest correlations with GY (Table 5) are shown in Figures 1 and 2, respectively. Figure 2 includes GY map.

The sand content displayed the highest values $\left(>700 \mathrm{~g} \mathrm{~kg}^{-1}\right)$ in the northeastern part of the experimental field, in contrast to the lowest values $\left(<400 \mathrm{~g} \mathrm{~kg}^{-1}\right)$ in the southwestern part. The $\mathrm{pH}$ outlined a similar pattern, despite a sharper shift from high values in the northeastern tip to low values in the rest of the field. However, $\mathrm{pH}$ range was rather tight, all values indicating moderate to strong alkalinity ( $\mathrm{pH}$ range, 8.3-8.7). Lastly, total organic $\mathrm{C}$ exhibited a pattern opposed to sand content: very low $\mathrm{C}$ values $\left(<4 \mathrm{~g} \mathrm{~kg}^{-1}\right)$ in the north-eastern area where sand was particularly abundant, in exchange for quite higher values $\left(>8 \mathrm{~g} \mathrm{~kg}^{-1}\right)$ in the southern part of the field where sand was counter-balanced by higher clay and silt content.

GS at stem elongation (March 25) exhibited NDVI values indicating stunted growth $(\sim 0.50)$ in the northeastern part of the field, compared to normal growth $(>0.60)$ in the southern part. PPVI at the same wheat stage (March 31) showed a smoother pattern between low (north-eastern) and high (southern) part of the field, despite an intrinsic variation (CV) similar to NDVI (Table 3). Finally, GY was actually very low $\left(<3 \mathrm{Mg} \mathrm{ha}^{-1}\right)$ in the northeastern part of the field, whence values gradually increased to top wheat yield $\left(>8 \mathrm{Mg} \mathrm{ha}^{-1}\right)$ in the southwestern part of the field.

\section{Homogeneous areas}

\section{Clustering}

PCA on soil properties, proximal and remote vegetation indices accounted for a respective 68,93 and $97 \%$ of the total vari-

Table 5. Pearson's correlations (r) between soil parameters, proximal and remote vegetation indices, on one side, and plant traits, on the other side.

\begin{tabular}{|c|c|c|c|c|c|c|c|c|c|}
\hline & Height & DBY & HI & GY & $\mathrm{S} / \mathrm{m}^{2}$ & $G / S$ & MGW & TW & GPC \\
\hline \multicolumn{10}{|c|}{ Soil parameters } \\
\hline Sand & $-0.85^{*}$ & $-0.92 *$ & $-0.57^{*}$ & $-0.91^{*}$ & -0.15 & $-0.81^{*}$ & $-0.63^{*}$ & 0.04 & 0.41 \\
\hline Silt & $0.84^{*}$ & $0.90^{*}$ & $0.54^{*}$ & $0.89 *$ & 0.12 & $0.80^{*}$ & $0.59 *$ & -0.01 & -0.40 \\
\hline Clay & $0.77^{*}$ & $0.84^{*}$ & $0.59 *$ & $0.85^{*}$ & 0.21 & $0.73^{*}$ & $0.67^{*}$ & -0.09 & $-0.42 * *$ \\
\hline $\mathrm{pH}$ & $-0.86^{*}$ & $-0.87^{*}$ & $-0.56^{*}$ & $-0.87^{*}$ & -0.03 & $-0.85^{*}$ & $-0.58^{*}$ & 0.02 & 0.39 \\
\hline $\mathrm{CaCO}_{3}$ & $0.48 * *$ & $0.43^{* *}$ & 0.38 & $0.45^{* *}$ & -0.03 & 0.38 & $0.47^{* *}$ & 0.20 & -0.10 \\
\hline $\mathrm{C}$ & $0.85^{*}$ & $0.86^{*}$ & $0.54^{*}$ & $0.85^{*}$ & 0.01 & $0.83^{*}$ & $0.48 * *$ & -0.28 & $-0.53^{* *}$ \\
\hline $\mathrm{N}$ & $0.64 *$ & $0.64^{*}$ & 0.30 & $0.61^{*}$ & -0.13 & $0.63^{*}$ & 0.31 & -0.05 & -0.15 \\
\hline $\mathrm{C} / \mathrm{N}$ & $0.76^{*}$ & $0.78 *$ & $0.55^{*}$ & $0.79^{*}$ & 0.10 & $0.73^{*}$ & $0.48^{* *}$ & -0.35 & $-0.63^{*}$ \\
\hline $\mathrm{P}$ & $0.43^{* *}$ & 0.33 & 0.36 & 0.33 & 0.14 & 0.29 & 0.30 & -0.35 & -0.50 ** \\
\hline $\mathrm{K}$ & -0.31 & -0.32 & -0.21 & -0.33 & 0.11 & -0.33 & -0.25 & -0.12 & -0.11 \\
\hline $\mathrm{Ca}$ & -0.27 & -0.27 & -0.34 & -0.32 & -0.16 & -0.32 & -0.29 & -0.02 & -0.03 \\
\hline $\mathrm{Mg}$ & -0.06 & -0.03 & -0.15 & -0.08 & 0.02 & -0.12 & -0.11 & -0.12 & -0.21 \\
\hline $\mathrm{Na}$ & -0.16 & -0.21 & $-0.46^{* *}$ & -0.30 & -0.05 & -0.24 & -0.25 & 0.10 & 0.18 \\
\hline CEC & -0.16 & -0.05 & -0.15 & -0.08 & 0.12 & -0.21 & -0.18 & -0.09 & -0.11 \\
\hline \multicolumn{10}{|c|}{ Proximal indices } \\
\hline NT 3/25 & $0.76^{*}$ & $0.80^{*}$ & $0.38 * *$ & $0.80^{*}$ & 0.03 & $0.77^{*}$ & $0.52 *$ & -0.27 & $-0.41^{* *}$ \\
\hline GS $3 / 25$ & $0.87^{*}$ & $0.93^{*}$ & $0.60^{*}$ & $0.96^{*}$ & -0.06 & $0.89 *$ & $0.67^{*}$ & -0.21 & $-0.51^{*}$ \\
\hline NT 4/8 & $0.80 *$ & $0.88^{*}$ & $0.46^{*}$ & $0.89 *$ & -0.18 & $0.79 *$ & $0.58^{*}$ & -0.15 & $-0.36^{* *}$ \\
\hline GS 4/8 & $0.94 *$ & $0.84^{*}$ & $0.67^{*}$ & $0.88^{*}$ & 0.07 & $0.87^{*}$ & $0.76^{*}$ & -0.12 & $-0.53^{*}$ \\
\hline NT 4/24 & $0.88 *$ & $0.86^{*}$ & $0.55^{*}$ & $0.88^{*}$ & -0.11 & $0.85^{*}$ & $0.69^{*}$ & -0.02 & -0.29 \\
\hline GS 4/24 & $0.91^{*}$ & $0.75^{*}$ & $0.63^{*}$ & $0.78^{*}$ & 0.09 & $0.77^{*}$ & $0.78^{*}$ & 0.01 & $-0.41^{* *}$ \\
\hline \multicolumn{10}{|c|}{ Remote indices } \\
\hline PPCI 3/15 & $0.71^{*}$ & $0.77^{*}$ & $0.46^{*}$ & $0.75^{*}$ & 0.01 & $0.69 *$ & $0.57^{*}$ & $-0.30^{*}$ & $-0.54^{*}$ \\
\hline PPVI 3/15 & $0.86^{*}$ & $0.93^{*}$ & $0.61^{*}$ & $0.91^{*}$ & 0.01 & $0.87^{*}$ & $0.71^{*}$ & $-0.39 *$ & $-0.68 *$ \\
\hline PPCI $3 / 31$ & $0.76^{*}$ & $0.83^{*}$ & $0.45^{*}$ & $0.79 *$ & 0.07 & $0.74^{*}$ & $0.61^{*}$ & $-0.32 *$ & $-0.59^{*}$ \\
\hline PPVI 3/31 & $0.87 *$ & $0.94^{*}$ & $0.60^{*}$ & $0.92 *$ & 0.05 & $0.88^{*}$ & $0.70^{*}$ & $-0.37^{*}$ & $-0.69 *$ \\
\hline PPCI 4/16 & $0.84^{*}$ & $0.90^{*}$ & $0.58^{*}$ & $0.89 *$ & 0.01 & $0.84^{*}$ & $0.68^{*}$ & $-0.42 *$ & $-0.67^{*}$ \\
\hline PPVI 4/16 & $0.84^{*}$ & $0.91^{*}$ & $0.57^{*}$ & $0.89 *$ & 0.04 & $0.86^{*}$ & $0.67^{*}$ & $-0.36^{*}$ & $-0.67^{*}$ \\
\hline
\end{tabular}

DBY, dry biomass yield; HI, harvest index; GY, grain yield; S/m², spike density; G/S, grains per spike; MGW, mean grain weight; TW, test weight; GPC, grain protein content; NT, N-Tester; GS, GreenSeeker; PPCI, PurePixel Chlorophyll Index; PPVI, PurePixel Vegetation Index; CEC, cation exchange capacity. r values significant at ** $\leq 0.05$ and $*$ P $\leq 0.01$, respectively $(\mathrm{n}=24,36$ and 131 for the respective correlations with soil parameters, proximal and remote indices). 
ance explained by the first two PCs (data not shown). Maps originating from clustering are shown in Figure 3. The three maps show the $\mathrm{L}$ and $\mathrm{H}$ potential area in the high and low part of the field, respectively. However, differences in shape and, especially, size may be evinced among the three areas (Table 6). Clustering based on soil parameters $\left(\mathrm{CLU}_{\mathrm{sp}}\right)$ and proximal indices $\left(\mathrm{CLU}_{\mathrm{pi}}\right)$ partitioned a similar share of the experimental field to the $\mathrm{L}$ and $\mathrm{H}$ area ( 25 and $29 \%$ in $\mathrm{CLU}_{\mathrm{sp}} ; 25$ and $33 \%$ in $\mathrm{CLU}_{\mathrm{pi}}$ ). Compared to this, clustering based on remote indices (CLU $\left.\mathrm{Ci}_{\mathrm{ri}}\right)$ apportioned the highest share to the $\mathrm{H}$ area (46\%), and the lowest share to the L area (16\%).

\section{Cluster comparison}

Morphological, yield and quality traits exhibited a different profile in the homogeneous areas obtained with the three criteria (Table 6). CLU $\mathrm{Sp}_{\mathrm{sp}}$ determined lower differences among trait levels. Especially in the case of GY that is the main trait, the gap between $\mathrm{H}$ and $\mathrm{L}$ level was quite narrower in $\mathrm{CLU}_{\mathrm{sp}}\left(2.56 \mathrm{Mg} \mathrm{ha}^{-1}\right)$ than in $\mathrm{CLU}_{\text {pi }}\left(3.96 \mathrm{Mg} \mathrm{ha}^{-1}\right)$ and $\mathrm{CLU}_{\text {ri }}\left(3.87 \mathrm{Mg} \mathrm{ha}^{-1}\right)$, and no statistical difference was found between $\mathrm{I}$ and $\mathrm{H}$ in $\mathrm{CLU}_{\text {sp. }}$. The same pattern was shown in the case of DBY. Likewise, TW and GPC were more differentiated in $\mathrm{CLU}_{\mathrm{pi}}$ and $\mathrm{CLU}$ ri, although these two quality traits outlined a decreasing trend between $\mathrm{L}$ and $\mathrm{H}$ area, in contrast to DBY and GY.

Hence, it is perceived that $\mathrm{CLU}_{\mathrm{sp}}$ was less prone to indicate field portions at different crop performance, compared to $\mathrm{CLU}_{\mathrm{pi}}$ and $\mathrm{CLU}_{\mathrm{ri}}$. However, a major difference is seen between these two: $\mathrm{CLU}_{\text {pi }}$ determined an almost $100 \% \mathrm{GY}$ increase between $\mathrm{L}$ and $\mathrm{H}$ zone, while partitioning the field surface into three areas of comparable size (between 25 and 42\%). Conversely, CLU $\mathrm{C}_{\mathrm{ri}}$ showed a similar GY increase between $\mathrm{L}$ and $\mathrm{H}$, but these two field portions greatly differed in size (16 vs 46\%, respectively).

The analysis of agreement between cell levels determined by clustering with the three criteria, and DBY and GY, showed a better match for proximal and, to a lesser extent, remote indices, compared to soil parameters (Table 7). It is therefore demonstrated that spectral vegetation indices supplied a more reliable indication of yield potential, beside providing a stronger differentiation of DBY and GY (Table 6). DBY staged a stronger agreement with $\mathrm{CLU}_{\mathrm{sp}}$ and $\mathrm{CLU}_{\mathrm{pi}}$ than GY, in exchange for a weaker agreement in CLU $\mathrm{ri}_{\mathrm{ri}}$.

\section{Discussion}

The experimental area chosen for this study, based on previous yield records, has portrayed a remarkable variation in wheat crop characteristics. This has resulted in a ca. 2.5-fold increase in DBY and GY between minimum and maximum (Table 4), and a $100 \%$ GY increase between $\mathrm{L}$ and $\mathrm{H}$ area with clustering based on proximal and remote vegetation indices (Table 6). These are among the highest variations observed in wheat studies (Song et al., 2009; Peralta et al., 2015; Quebrajo et al., 2015; Basso et al., 2016).

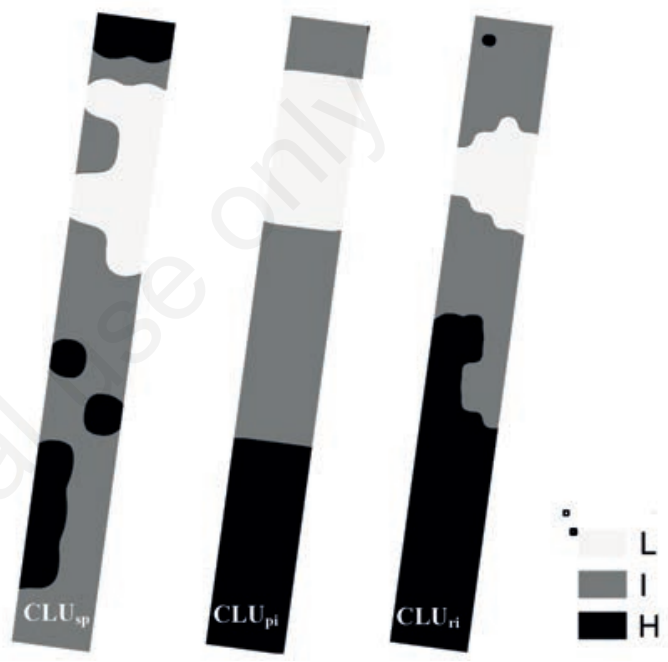

Figure 3. Maps originating from clustering based on soil parameters $\left(C L U_{s p}\right)$, proximal $\left(C_{C L}\right)$ and remote spectral vegetation indices $\left(\mathrm{CLU}_{\mathrm{ri}}\right)$. L, I, H mean low, intermediate and high potential area, respectively.

Table 6. Plant morphology, yield and quality traits in field areas clustered on the basis of soil parameters $\left(C^{2} U_{\text {sp }}\right)$, proximal $\left(C L U_{\text {pi }}\right)$ and remote spectral vegetation indices $\left(\mathrm{CLU}_{\mathrm{ri}}\right)$.

\begin{tabular}{|c|c|c|c|c|c|c|c|c|c|c|}
\hline Level & $\%$ area & $\begin{array}{l}\text { Height } \\
\text { (m) }\end{array}$ & $\begin{array}{c}\text { DBY } \\
\left(\mathrm{Mg} \mathrm{ha}^{-1}\right)\end{array}$ & $\begin{array}{c}\text { HI } \\
(w / w)\end{array}$ & $\begin{array}{c}\text { GY } \\
\left(\mathrm{Mg} \mathrm{ha}^{-1}\right)\end{array}$ & $\begin{array}{c}\mathrm{S} / \mathrm{m}^{2} \\
\left(\text { no. } \mathrm{m}^{-2}\right)\end{array}$ & $\begin{array}{c}\text { G/S } \\
\left(\text { no. spike }{ }^{-1} \text { ) }\right.\end{array}$ & $\begin{array}{l}\text { MGW } \\
\text { (mg) }\end{array}$ & $\begin{array}{c}\text { TW } \\
\left(\mathrm{dg} \mathrm{L}^{-1}\right)\end{array}$ & $\begin{array}{c}\text { GPC } \\
\left(\mathrm{g} \mathrm{kg}^{-1}\right)\end{array}$ \\
\hline \multicolumn{11}{|l|}{$\mathrm{CLU}_{\mathrm{sp}}$} \\
\hline L & 25 & $0.64^{\mathrm{b}}$ & $7.87^{\mathrm{b}}$ & $0.47^{\mathrm{b}}$ & $4.28^{b}$ & 571 & $16.1^{\mathrm{b}}$ & $37.6^{\mathrm{b}}$ & 83.4 & 107.6 \\
\hline I & 46 & $0.82^{\mathrm{a}}$ & $11.61^{\mathrm{a}}$ & $0.51^{\mathrm{a}}$ & $6.72^{\mathrm{a}}$ & 574 & $28.2^{\mathrm{a}}$ & $40.0^{\mathrm{a}}$ & 83.8 & 100.9 \\
\hline $\mathrm{H}$ & 29 & $0.83^{\mathrm{a}}$ & $11.98^{\mathrm{a}}$ & $0.49^{\mathrm{ab}}$ & $6.84^{\mathrm{a}}$ & 586 & $27.2^{\mathrm{a}}$ & $39.3^{\mathrm{ab}}$ & 83.7 & 97.7 \\
\hline \multicolumn{11}{|l|}{$\mathrm{CLU}_{\mathrm{pi}}$} \\
\hline L & 25 & $0.69^{c}$ & $7.63^{c}$ & $0.47^{\mathrm{b}}$ & $4.09^{c}$ & 563 & $14.9^{c}$ & $37.4 \mathrm{~b}$ & $83.7^{\mathrm{ab}}$ & $110.0^{\mathrm{a}}$ \\
\hline I & 42 & $0.84^{\mathrm{b}}$ & $10.69^{b}$ & $0.50^{\mathrm{a}}$ & $6.11^{\mathrm{b}}$ & 592 & $25.5^{\mathrm{b}}$ & $39.7 \mathrm{a}$ & $84.1^{\mathrm{a}}$ & $101.3^{a b}$ \\
\hline $\mathrm{H}$ & 33 & $0.93^{\mathrm{a}}$ & $13.61^{\mathrm{a}}$ & $0.52^{\mathrm{a}}$ & $8.05^{\mathrm{a}}$ & 560 & $32.8^{\mathrm{a}}$ & $40.4 a$ & $83.1^{\mathrm{b}}$ & $93.6^{\mathrm{b}}$ \\
\hline \multicolumn{11}{|l|}{$\mathrm{CLU}_{\mathrm{ri}}$} \\
\hline L & 16 & $0.67^{\mathrm{c}}$ & $6.88^{\mathrm{c}}$ & $0.48^{\mathrm{b}}$ & $3.83^{\mathrm{c}}$ & 583 & $16.6^{\mathrm{c}}$ & $38.1^{\mathrm{c}}$ & $84.0^{\mathrm{a}}$ & $108.6^{\mathrm{a}}$ \\
\hline I & 38 & $0.75^{\mathrm{b}}$ & $9.84^{\mathrm{b}}$ & $0.49^{\mathrm{b}}$ & $5.51^{\mathrm{b}}$ & 572 & $22.1^{\mathrm{b}}$ & $38.9^{\mathrm{b}}$ & $83.9^{\mathrm{a}}$ & $104.4^{b}$ \\
\hline $\mathrm{H}$ & 46 & $0.86^{\mathrm{a}}$ & $13.06^{\mathrm{a}}$ & $0.51^{\mathrm{a}}$ & $7.70^{\mathrm{a}}$ & 588 & $30.2^{\mathrm{a}}$ & $40.1^{\mathrm{a}}$ & $83.3^{\mathrm{b}}$ & $94.9^{c}$ \\
\hline
\end{tabular}

L, I, H, mean low, intermediate and high potential yield area, respectively; DBY, dry biomass yield; HI, harvest index; GY, grain yield (at 13\% moisture); S/m², spike density; G/S, grains per spike; MGW, mean grain weight;

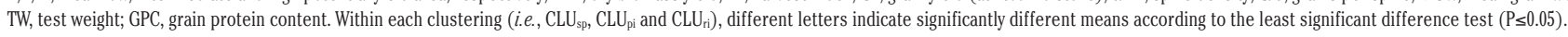


The three domains of data acquisition, soil analysis, proximal and remote canopy sensing, have proved generally able to represent the variable crop behaviour, which is the premise for homogeneous area delineation. Owing to the highly significant correlations of many soil and spectral vegetation variables with DBY and GY (Table 5), their aggregation into compound variables through PCA was seen a necessary step. PCA successfully served this task, as demonstrated by the high proportion of the original variance explained by the first two PCs in the 14 soil parameters $(68 \%), 6$ proximal (93\%) and 6 remote vegetation indices (97\%).

PCA represents a common approach for reducing the number of variables, which is also echoed in studies on wheat spatial variation (Casa and Castrignanò, 2008; Peralta et al., 2015). In our work, submitting spectral vegetation indices to PCA was aimed at delineating homogeneous areas based on data covering a more extended wheat stage, allowing key practices (e.g., nitrogen top dress fertilisation) to be more easily carried out in a frame of SSM. The use of PCA for spectral vegetation indices was supported by the high correlations that the four proximal/remote indices maintained with DBY and GY across the surveyed stages (Table 5). The high correlations between the three dates for each index (average $\mathrm{r}$ between 0.81 and 0.91 ; data not shown also supported this choise). Furthermore, it was a straightforward option to join PPCI and PPVI that are determined simultaneously, despite the intrinsic difference of a chlorophyll (PPCI) vs growth (PPVI) index. Thus it appeared sensible to do the same with NT and GS that are the two equivalent proximal traits.

The complex of these choices led to the delineation of homogeneous areas whose robustness was proved by their ability to indicate field areas consistently matching growth potential (L, I, H area) with analogous differentiation of morphological and yield traits (Table 6), and by the good agreement between area level set with the three criteria, and the level of DBY and GY independently clustered with the same procedure (Table 7). Attempts to delineate homogeneous areas based on a single soil parameter or vegetation index resulted in a similar relationship with DBY and GY (not shown), provided that the variable chosen had a good correlation with either trait. However, which variable will be best correlated with final yield cannot be anticipated during crop growth. Thus, in our work we combined several variables into a few PCs resulting in better-buffered homogeneous areas. It results that, from a practical viewpoint, either soil data could be used as a whole, or crop sensing could be conducted once during the surveyed stages, to discriminate areas at different yield potential.

Lastly, adoption of more than three levels for both homogeneous areas and GY is seldom echoed in the literature on wheat (Farid et al., 2016). Our decision to stop at three, beside limiting

Table 7. Degree of agreement (\% cells) between the three levels (L, I and $\mathrm{H}$ ) of dry biomass yield (DBY) and grain yield (GY), on one side, and field clusters based on soil parameters $\left(C L U_{s p}\right)$, proximal $\left(C L U_{\mathrm{pi}}\right)$ and remote spectral vegetation indices $\left(C L U_{\mathrm{ri}}\right)$, on the other side.

\begin{tabular}{lcccc} 
Trait & Degree of agreement & CLU $_{\mathrm{sp}}$ & $\mathrm{CLU}_{\mathrm{pi}}$ & $\mathrm{CLU}_{\mathbf{r i}}$ \\
DBY & Agreement & 54 & 67 & 79 \\
& Mild disagreement & 38 & 33 & 21 \\
& Strong disagreement & 8 & - & - \\
GY & Agreement & 50 & 89 & 72 \\
& Mild disagreement & 46 & 11 & 28 \\
& Strong disagreement & 4 & - & - \\
\hline
\end{tabular}

field patchiness to the benefit of simpler crop practices (Paice et al., 1998), is supported by the fact that choosing more than three levels was shown to provide modest advantages in the amount of explained variance (Fraisse et al., 2001; Tagarakis et al., 2013).

Homogeneous areas obtained through clustering based on spectral vegetation indices vs. soil parameters determined a wider ranking of DBY, GY and associated parameters (Table 6), and a better cell-to-cell agreement with DBY and GY (Table 7). However, the soil parameters used in this study (Table 2) are rather consistent in time, whereas spectral vegetation indices are intrinsically variable between years, depending on growth conditions affecting canopy reflectance properties (Diacono et al., 2013). Thus, soil analysis supplies data that can be used for more years, whereas spectral vegetation indices need to be assessed each year. In exchange for this, canopy sensing involves less burden and cost than soil analysis, especially in the case of remote sensing.

A combined use of soil analysis and vegetation indices could also be envisaged (Song et al., 2009). However, in the cited work soil parameters and a vegetation index were combined with GY to delineate homogeneous areas, so the additive effect of vegetation index to soil analysis cannot be ascertained independently from GY. In contrast to this, we clustered soil and vegetation data alone, and used DBY, GY and related traits to rate the appropriateness of the clusters obtained. It is a sounder approach not to use crop yield in homogeneous area delineation, as yield is a grower's ultimate goal and cannot be predicted months before harvesting. This choice is supported by other sources in the literature (Peralta et al., 2015; Farid et al., 2016).

Remote sensing of spectral vegetation indices has been focused only recently in wheat studies addressing the establishment of variable rate $\mathrm{N}$ fertilisation (Basso et al., 2016) and GY prediction (Zhang and Liu, 2014; Dalla Marta et al., 2015). Other works that allegedly refer to remote sensing, actually address proximal sensing. Of the two index categories, general crop status and chlorophyll content, the cited works are equally in favour of the former (Dalla Marta et al., 2015) and the latter category (Zhang and Liu, 2014), and a mix of them (Basso et al., 2016). Data in our work do not indicate a clear advantage for either category (Table 5), so their combination by means of PCA appears once more advisable. However, in this specific subject the level of knowledge is still insufficient for univocal consensus to be reached.

Finally, the similar good performance of proximal and remote vegetation indices demonstrates the quality of remote data achieved by commercial systems. This is in agreement with a recent work where proximal sensing was used for validation of satellite images (Basso et al., 2016).

\section{Conclusions}

Advantages and disadvantages of homogeneous area delineation using soil parameters vs. proximal and remote spectral vegetation indices appear non-univocal, in light of the above discussion. This work based on one year of wheat cropping in a region where wheat rotation with other crops is the standard good practice, represents a showcase of the three systems' potential. Nevertheless, the approach used in data processing has resulted in a robust delineation of homogeneous areas, as proved by the substantial consistency with final yield and related attributes. Further studies shall address the inter-annual variation of the proposed methods, in order to corroborate these findings and develop research driven strategies of practical use. 


\section{References}

Basso B, Fiorentino C, Cammarano D, Schulthess U, 2016. Variable rate nitrogen fertilizer response in wheat using remote sensing. Precis. Agric. 17:168-82.

Blackmore S, 2000. The interpretation of trends from multiple yield maps. Comput. Electron. Agric. 26:37-51.

Bushong JT, Mullock JL, Miller EC, Raun WR, Klatt AR, Arnall DB, 2016. Development of an in-season estimate of yield potential utilizing optical crop sensors and soil moisture data for winter wheat. Precis. Agric. 17:451-69.

Calvo NIR, Rozas HS, Echeverria H, Diovisalvi N, 2015. Using canopy indices to quantify the economic optimum nitrogen rate in spring wheat. Agron. J. 107:459-65.

Casa R, Castrignanò A, 2008. Analysis of spatial relationships between soil and crop variables in a durum wheat field using a multivariate geostatistical approach. Eur. J. Agron. 28:331-42.

Chang D, Zhang J, Zhu L, Ge SH, Li PY, Liu GS, 2014. Delineation of management zones using an active canopy sensor for a tobacco field. Comput. Electron. Agric. 109:172-78.

Chattaraj S, Chakraborty D, Garg RN, Singh GP, Gupta VK, Singh S, Singh R, 2013 Hyperspectral remote sensing for growthstage-specific water use in wheat. Field Crop. Res. 144:179-91.

Chen C, Pan J, Lam SK, 2014. A review of precision fertilization research. Environ. Earth Sci. 71:4073-80.

Ciesielski H, Sterckeman T, 1997. Determination of cation exchange capacity and exchangeable cations in soils by means of cobalt hexamine trichloride. Effects of experimental conditions. Agron. J. 17:1-7.

D.M. 13/09, 1999. Approvazione dei "Metodi ufficiali di analisi chimica del suolo". Ministry for Agricultural Politics. Gazzetta Ufficiale Supplemento Ordinario 248 of October 21, 1999 [in Italian].

Dalla Marta A, Grifoni D, Mancini M, Orlando F, Guasconi F, Orlandini S, 2015. Durum wheat in-field monitoring and earlyyield prediction: assessment of potential use of high resolution satellite imagery in a hilly area of Tuscany, Central Italy. J. Agr. Sci. 153:68-77.

Damian JM, De Castro Pias O.H., Santi AL, Di Virgilio N, Berghetti J, Barbanti L, Martelli R, 2016. Delineating management zones for precision agriculture applications: a case study on wheat in sub-tropical Brazil. Ital. J. Agron. 11:171-9.

Diacono M, Rubino P, Montemurro F, 2013. Precision nitrogen management of wheat. A review. Agron. Sustain. Dev. 33:219-41.

Dunteman GH, 1989. Principal component analysis. Sage Publications, Newbury Park, CA, USA.

Erdle K, Mistele B, Schmidhalter U, 2011. Comparison of active and passive spectral sensors in discriminating biomass parameters and nitrogen status in wheat cultivars. Field Crop. Res. 124:74-84.

Farid HU, Bakhsh A, Ahmad N, Ahmad A, Mahmood-Khan Z, 2016. Delineating site-specific management zones for precision agriculture. J. Agr. Sci. 154:273-86.

Fraisse CW, Sudduth KA, Kitchen NR, 2001. Delineation of sitespecific management zones by unsupervised classification of topographic attributes and soil electrical conductivity. T. ASAE 44:155-66.

Fridgen JJ, Kitchen NR, Sudduth KA, Drummond ST, Wiebold WJ, Fraisse CW, 2004. Management zone analyst (MZA). Agron. J. 96:100-8.

Grohs DS, Bredemeier C, Poletto N, Mundstock CM, 2011. Validation of model for wheat yield prediction potential using active optical sensor. Pesq. Agropec. Brasil. 46:446-9.

Guastaferro F, Castrignanò A, De Benedetto D, Sollitto D, Troccoli A, Cafarelli B, 2010. A comparison of different algorithms for the delineation of management zones. Precis. Agric. 11:600-20.

Jin N, Tao B, Ren W, Feng M, Sun R, He L, Zhuang W, Yu Q, 2016. Mapping irrigated and rainfed wheat areas using multitemporal satellite data. Remote Sens. 8:1-19.

Kitchen NR, Sudduth KA, Myers DB, Drummond ST, Hong SY, 2005. Delineating productivity zones on claypan soil fields apparent soil electrical conductivity. Comput. Eelectron. Agric. 46:285-308.

Li Y, Shi Z, Wu HX, Li F, Li HY, 2013, Definition of management zones for enhancing cultivated land conservation using combined spatial data. Environ. Manage. 52:792-806.

Li Y, Shi Z, Wu C, Li HY, Li F, 2008. Determination of potential management zones from soil electrical conductivity, yield and crop data. J. Zhejiang Univ. Sci. 9:68 $\square 76$.

Lowrance C, Fountas S, Liakos V, Vellidis G, 2016. EZZone-An online tool for delineating management zones. Proc. 13th Intl. Conf. Precis. Agric., St. Louis, MI, USA.

Macnack N, Khim BC, Mullock J, Raun W, 2014. In-season prediction of nitrogen use efficiency and grain protein in winter wheat (Triticum aestivum L.). Commun. Soil Sci. Plan. 45:2480-94.

Mallarino AP, Oyarzabal ES, Hinz PN, 1999. Interpreting withinfield relationships between crop yields and soil and plant variables using factor analysis. Precis. Agric. 1:15-25.

Mann KK, Schumann AW, Obreza TA, 2011. Delineating productivity zones in a citrus grove using citrus production tree growth and temporally stable soil data. Precis. Agric. 12:457-72.

McBratney A, Whelan B, Ancev T, Bouma J, 2005. Future directions of precision agriculture. Precis. Agric. 6:7-23.

Milne AE, Webster R, Ginsburg D, Kindred D, 2012. Spatial multivariate classification of an arable field into compact management zones based on past crop yields. Comput. Electron. Agric. 80:17-30.

Mulla DJ, Schepers JS, 1997. Key processes and properties for site-specific soil and crop management. In: F.J. Pierce, E.J. Sadler (Eds.), The state of site-specific management for agriculture. ASA/CSSA/SSSA, Madison, WI, USA, pp 1-18.

Orsini L, Rémy JC, 1976. Utilisation du chlorure de cobaltihexammine pour la détermination simultanée de la capacité d'échange et des bases échangeables des sols. Sci. Sol 4:26975 [in French].

Ozcan O, Musaoglu N, Ustundag B, 2014. Crop water requirement estimation of wheat cultivated fields by remote sensing and GIS. J. Food Agric. Environ. 12:289-93.

Paice MER, Day W, Rew LJ, Howard A, 1998. A stochastic simulation model for evaluating the concept of patch spraying. Weed Res. 38:373-88.

Patil SS, Patil VC, Al-Gaadi KA, 2010. Wheat acreage, productivity and production estimation through remote sensing and GIS techniques. Aust. J. Basic Appl. Sci. 4:3132-8.

Peralta NR, Costa JL, Balzarini M, Castro Franco M, Cordoba M, Bullock D, 2015. Delineation of management zones to improve nitrogen management of wheat. Comput. Electron. Agric. 110:103-13.

Pierce FJ, Nowak P, 1999. Aspects of precision agriculture. Adv. Agron. 67:1-85.

Quebrajo L, Perez-Ruiz M, Rodriguez-Lizana A, Aguera J, 2015. An approach to precise nitrogen management using hand-held crop sensor measurements and winter wheat yield mapping in a Mediterranean environment. Sensors 15:5504-17. 
Raun WR, Solie JB, Johnson GV, Stone ML, Lukina EV, Thomason WE, Schepers JS, 2001. In-season prediction of potential grain yield in winter wheat using canopy reflectance. Agro. J. 93:131-8.

Reichardt J, Jürgens C, 2009. Adoption and future perspective of precision farming in Germany: results of several surveys among different agricultural target groups. Precis. Agric. 10:73-94.

Samborski SM, Gozdowski D, Walsh OS, Lamb DW, Stepien M, Gacek ES, Drzazga T, 2015. Winter wheat genotype effect on canopy reflectance: implications for using NDVI for in-season nitrogen topdressing recommendations. Agron. J. 107:2097106.

Song XY, Wang JH, Huang WJ, Liu LY, Yan GJ, Pu RL, 2009. The delineation of agricultural management zones with high resolution remotely sensed data. Precis. Agric. 10:471-87.

Stafford JV, 2000. Implementing precision agriculture in the $21 \mathrm{st}$ century. J. Agr. Eng. Res. 76:267-75.
Sudduth KA, Drummond ST, 2007. Yield editor: software for removing errors from crop yield maps. Agron. J. 99:1471-82.

Tagarakis A, Liakos V, Fountas S, Koundouras S, Gemtos TA, 2013. Management zones delineation using fuzzy clustering techniques in grapevines. Precis. Agric. 14:18-39.

Tucker CJ, 1979. Red and photographic infrared linear combinations for monitoring vegetation. Remote Sens. Environ. 8:127-50.

Yousefi MR, Razdari AM, 2015. Application of GIS and GPS in precision agriculture (a review). Int. J. Adv. Biol. Biom. Res. 3:7-9.

Zadoks JC, Chang TT, Konzak CF, 1974. A decimal code for the growth stages of cereals. Weed Res. 14:415-21.

Zhang C, Kovacs J, 2012. The application of small unmanned aerial systems for precision agriculture: a review. Precis. Agric. 13:693-712.

Zhang S, Liu L, 2014. The potential of the MERIS terrestrial chlorophyll index for crop yield prediction. Remote Sens. Lett. 5:733-42. 